\title{
Postherpetic Neuralgia: From Preclinical Models to the Clinic
}

\author{
Ada Delaney, ${ }^{*}$ Lesley A. Colvin, ${ }^{\dagger}$ Marie T. Fallon, ${ }^{*}$ Robert G. Dalziel, ${ }^{\S}$ Rory Mitchell,${ }^{\mathbb{q}}$ \\ and Susan M. Fleetwood-Walker* \\ *Centre for Neuroregeneration, ${ }^{\dagger}$ Department of Anaesthesia, Critical Care, and Pain Medicine, ${ }^{\ddagger}$ Edinburgh Cancer Research \\ Centre, Western General Hospital, ${ }^{\S}$ The Roslin Institute and Centre for Infectious Diseases, and ${ }^{\mathrm{II}}$ Centre for Integrative \\ Physiology, College of Medicine and Veterinary Medicine, University of Edinburgh, Edinburgh, United Kingdom
}

Summary: Postherpetic neuralgia (PHN), a common complication of herpes zoster, which results from reactivation of varicella zoster virus, is a challenging neuropathic pain syndrome. The incidence and severity of herpes zoster and PHN increases with immune impairment or age and may become a greater burden both in terms of health economics and individual suffering. A clearer understanding of the underlying mechanisms of this disease and translation of preclinical outcomes to the clinic may lead to more efficacious treatment options. Here we give an overview of recent findings from preclinical models and clinical research on PHN. Key Words: Postherpetic neuralgia, herpes zoster, varicella zoster virus, animal model, chronic pain, analgesia.

\section{INTRODUCTION}

Postherpetic neuralgia is a challenging chronic neuropathic pain syndrome. It occurs after reactivation of a latent infection by varicella zoster virus (VZV) within sensory neurons ${ }^{1}$ causes the distinctive clinical condition known as herpes zoster (HZ) and commonly called shingles. Although most patients recover completely after several months, a number will be left with persistent pain, known as postherpetic neuralgia (PHN). Currently available therapies are of variable benefit, and there is a clear need to improve our clinical approach either by improved treatments or by developing effective prevention strategies. ${ }^{1,2}$ The nature of the interaction between the virus and host cells is unclear and underinvestigated. The promise of eventual eradication by vaccination programs remains to be properly evaluated.

The etiology of disease progression is poorly understood. After resolution of the primary infection, known as varicella or chickenpox, VZV establishes a latent infection in sensory ganglia that persists for the lifetime of the host. ${ }^{3}$ In some circumstances, often associated with increasing age or in situations of immune compromise, $\mathrm{HZ}$ may develop. ${ }^{4,5}$ Clinical features of $\mathrm{HZ}$ can be vari-

Address correspondence and reprint requests to: Susan M. Fleetwood-Walker, Ph.D., Centre for Neuroregeneration, Chancellor's Building, 49 Little France Crescent, University of Edinburgh, EH16 4SB, UK. E-mail: s.m.fleetwood-walker@ed.ac.uk. able and include pain and abnormal sensations that may continue after the development of PHN. ${ }^{6-11}$ The incidence of $\mathrm{HZ}$ and PHN is difficult to estimate accurately because of inconsistencies in diagnosis and data collection. Studies indicate an incidence of 5.23 cases of $\mathrm{HZ}$ per 1000 person-years, with $13.7 \%$ of those having evidence of PHN after 3 months, or an incidence of 0.4 per 1000 person-years for PHN (compared with 0.15 for diabetic neuropathy). ${ }^{12,13}$ Estimates for $\mathrm{HZ}$ range from 5 to 12 cases per 1000 each year over all age groups. ${ }^{14}$

\section{POSTHERPETIC NEURALGIA}

In the majority of patients presenting with $\mathrm{HZ}$, the characteristic rash and associated acute zoster pain disappear within 1-2 months, but for some patients the acute symptoms of HZ may be followed by irreversible skin damage and sensory abnormalities, resulting in a persistent pain that can continue for months or years. Postherpetic neuralgia is the most common complication of HZ. ${ }^{15}$ Risk factors include age, severity of acute HZ pain, extent of rash, and presence and duration of prodromal pain. ${ }^{16-18}$ Other complications of $\mathrm{HZ}$ can include encephalitis, retinitis, and pruritus. ${ }^{19}$

The likelihood of developing PHN is unclear, because definitions vary between studies, ${ }^{20}$ and there is a need for an evidence-based description of the pain syndrome associated with PHN. ${ }^{21}$ Postherpetic neuralgia can manifest as a constant or intermittent spontaneous pain; in 
addition, sensory stimuli can evoke pain (e.g., dynamic mechanical allodynia evoked by innocuous stimulation, such as light touching of the skin). ${ }^{22,23}$ In addition, impaired sleep, emotional distress, and depression are common. In combination, these manifestations of PHN can lead to a reduction in the quality of life and activity levels.

At present, zoster-associated pain is used to cover a continuum of pain from the start of prodrome to its resolution, with PHN reserved for cases of significant pain or painful abnormal sensations persisting beyond 3 months after the HZ rash. The time course for the development of persistent pain associated with PHN is between 90 and 120 days after rash appearance. ${ }^{24-27}$ The risk of PHN increases dramatically with age, from 3-4\% in adults aged $30-49$ years, to $21 \%$ in 60 - to 69 -yearolds, to $29 \%$ in 70 - to 79 -year-olds, and to $34 \%$ in adults over the age of 80 years. ${ }^{9,28}$ As the median age of the developed world population increases, PHN may become a greater burden.

Approximately $70 \%$ of PHN patients who also experience ongoing pain and severe dynamic mechanical allodynia show considerable signs of neuronal degeneration and loss of function within the affected tissues. Immunohistochemical investigations and punch biopsies of the affected dermatome show degeneration of small fiber afferents in the skin. ${ }^{29,30}$ Furthermore, functional studies investigating C-fiber axon reflex have demonstrated impaired or abolished chemically evoked antidromic vasodilatation in skin regions with intense dynamic allodynia, indicating a significant loss of cutaneous C-fiber afferents. $^{31,32}$ There is evidence that all sensory fiber types are affected in PHN, with constant pain possibly being associated with damage to nociceptive afferents and paroxysmal pain related to changes in $\mathrm{A} \beta$ fibers. ${ }^{33}$

Quantitative thermal sensory testing showed greatly increased heat pain thresholds in the affected dermatome of some chronic PHN patients. ${ }^{34}$ Thus, there is a subset of PHN patients with pain and loss of cutaneous C-nociceptor function in a region that is coextensive with allodynic skin. Mechanisms underlying allodynia in these patients are still unclear: different subcortical brain areas are activated than with spontaneous pain. ${ }^{35}$ There might also be hyperexcitability of nociceptive neurons at the spinal level, due to the loss of inhibitory GABAergic interneurons that occurs after peripheral nerve lesion. ${ }^{36}$

After peripheral nerve injury, there are alterations in input to the central nervous system, inducing changes in the sensory processing mechanisms within the spinal dorsal horn. This gives rise to the phenomenon of central sensitization resulting from the increased afferent input generated by injury and noxious stimuli. This increased excitability of nociceptive neurons in the dorsal horn leads to an exaggerated and extended response to subsequent sensory inputs. ${ }^{37}$ If central sensitization is estab- lished, normally innocuous tactile stimuli become capable of activating spinal cord pain signaling neurons via $\mathrm{A} \beta$ low-threshold mechanoreceptors. ${ }^{38}$ By this mechanism, light touching of the skin induces mechanical allodynia.

Several clinical observations support the concept of sensitized nociceptors and central sensitization in PHN patients. Approximately 30\% of patients with PHN experiencing ongoing pain and severe dynamic mechanical allodynia do not show any loss of sensory function in the affected area, indicating that in these particular groups of patients loss of neurons may be minimal or absent. Accordingly, thermal sensory thresholds in their region of greatest pain are either normal or even decreased, ${ }^{30,39}$ which may reflect peripheral nociceptor sensitization.

\section{PRECLINICAL EVALUATIONS}

In vivo models have been developed of the persistent nociception induced by VZV, which results in sensory sensitivity to mechanical and thermal stimuli. ${ }^{40-42}$ The development of behavioral sensitization is dependent on the viral titer injected, with the absence of thermal hyperalgesia observed by Hasnie et al. ${ }^{43}$ possibly a result of differences in the viral inoculum concentration. ${ }^{41}$ The events through which the presence of the virus in neurons induces sensory sensitivity remain obscure. Techniques to address this are emerging. ${ }^{44}$

Viral infection in the sensory dorsal root ganglia (DRG) is confirmed by the presence of the immediate early protein VZV IE62, a protein that is expressed during latency and that is known to be essential for VZV replication and expression in host cells. ${ }^{41,45,46}$ This protein has been shown to be associated with subpopulations of DRG neurons. ${ }^{41}$ Inoculation with different viral strains. in addition to those harvested from patients (with or without PHN), all showed the presence of VZV IE62 in DRG. ${ }^{43}$ Both VZV IE62 and IE63 were also present in DRG from an in vitro model of localized infection. ${ }^{47}$ Additionally, infection of DRG with VZV resulted in sensitivity to adrenergic stimulation, with a possible mechanism of norepinephrine sensitivity through either or both $\alpha_{1^{-}}$and $\beta_{1^{-}}$ adrenergic receptors. ${ }^{47}$

The association of VZV IE62 expression with particular subpopulations of sensory neurons suggest a possible route for influencing cellular mechanisms within these neurons. A key factor in the neural plasticity underlying neuropathic pain is altered gene expression in sensory DRG neurons. ${ }^{48-51}$ Phenotypic alterations in the expression of neurotransmitters, in particular neuropeptides, occurs in both damaged and neighboring afferents after nerve injury. ${ }^{49,52}$ After peripheral nerve injury within large-diameter DRG neurons, there is a marked increase in the expression of neuropeptide $\mathrm{Y},{ }^{49}$ but in small-diameter DRG neurons, galanin levels are shown to increase. ${ }^{49,52}$ 
Similar to the case with nerve injury, after VZV infection there is an upregulation of neuropeptide $Y$ and galanin in DRG neurons. ${ }^{41}$ In addition, there also appears to be some axonal damage after VZV infection, as indicated by the induction of activating transcription factor-3 (ATF-3) ${ }^{41}$ a protein that is upregulated after nerve axotomy. ${ }^{53}$ Whether this is accompanied by any lasting neurodegenerative changes remains to be established.

Increase in the excitability of the nociceptor terminal membrane (and therefore reduction in the amount of further depolarization required to initiate an action potential) occurs when terminals are exposed to sensitizing agents such as inflammatory mediators or neurotrophic factors released during tissue or nerve damage. ${ }^{50}$ Voltage-gated sodium channels $\left(\mathrm{Na}^{+}\right.$channels) are mainly responsible for the rising phase of the action potential, and after nerve injury accumulate in the axon at the injury site and along its length, resulting in foci of hyperexcitability and ectopic action potential discharge in the axon and cell body of injured sensory neurons. ${ }^{54,55}$ Normally, DRG neurons express a number of $\mathrm{Na}^{+}$channel transcripts ${ }^{56}$ that can be distinguished by their sensitivity to tetrodotoxin (TTX) ${ }^{57}$ Expression of the TTXsensitive $\mathrm{Na}_{\mathrm{v}} 1.3$ sodium channel is markedly increased after peripheral nerve damage $\mathrm{e}^{48,58}$ and after VZV infection. ${ }^{41}$ The related TTX-resistant $\mathrm{Na}_{\mathrm{v}} 1.8$ is also upregulated after VZV infection, ${ }^{41}$ which may represent a promising target, given that knockdown of $\mathrm{Na}_{\mathrm{v}} 1.8$ reduces nerve injury-induced behavioral sensitization. ${ }^{59}$ Indeed, the sodium channel blocking agents mexiletine and lamotrigine were effective in attenuating VZV-induced behavioral sensitization ${ }^{41}$ and are effective analgesics in models of nerve injury and in the clinic. ${ }^{60-63}$

A further phenotypic alteration observed in VZV infected DRG is an upregulation of the $\alpha_{2} \delta 1$ subunit of the voltage-gated calcium channel, ${ }^{41}$ which is also noted after nerve injury. ${ }^{64-66}$ Such an increase is of particular importance, because the subunit $\alpha_{2} \delta 1$ has been proposed as the key target of gabapentin, 67 which (probably by blocking this channel subunit) can suppress ectopic discharges of injured primary afferents and reverse injuryinduced allodynia. ${ }^{60,62,68-71}$ Gabapentin and its analogue pregabalin are effective in the treatment of neuropathic pain, including $\mathrm{PHN},{ }^{72-74}$ and can reduce VZV-induced behavioral reflex sensitization with either acute or chronic administration. ${ }^{41}$ Acute administration of the selective $\mu$-opioid receptor agonist DAMGO did not affect virusinduced behavioral reflex sensitization, ${ }^{41}$ whereas chronic administration of morphine did reverse VZV-induced mechanical sensitization. ${ }^{43}$

Although clearly a number of receptors and subsequent signaling pathways are involved in the central sensitization that results in sensory hyperexcitability in many chronic pain models, changes in NMDA receptor activation are consistently thought to be a crucial factor underlying central sensitization..$^{55,75,76}$ Human studies have demonstrated the potential of the NMDA antagonist ketamine in the treatment of various chronic pain conditions, although with significant adverse effects. ${ }^{77}$ Local spinal application of an NMDA receptor antagonist attenuated VZV-induced behavioral sensitization. ${ }^{41}$ In PHN patient trials, however, some oral NMDA receptor antagonists have not proved beneficial. ${ }^{78}$

Although the use of nonsteroidal anti-inflammatorytype drugs has not been extensively examined in PHN, ${ }^{79}$ the active isomer of ibuprofen, $(S)-(+)$-ibuprofen, can reverse VZV-induced mechanical allodynia. ${ }^{43}$ Additionally, the tricyclic antidepressant amitriptyline and the cannabinoid agonist WIN 55,212-2 were found to reverse VZV-induced mechanical allodynia, and both have been found effective in clinical trials for either PHN or other neuropathic conditions. ${ }^{43,80,81}$ In summary, these preclinical investigations have revealed similarities between a rodent model of chronic pain induced by VZV infection and models of chronic pain from peripheral nerve injury, although more investigation is needed to reveal whether there are physiological changes specific to the VZV model.

Another issue often overlooked in preclinical development of therapeutic approaches is quality of life, which for a neuropathic pain patient is considerably reduced not only as a result of pain levels but in addition by considerable comorbidity, such as anxiety and depression. ${ }^{82,83}$ The animal model of VZV infection has been assessed recently through use of the open-field paradigm to determine anxiety-like behaviors as a measure of integrated pain behavior reflecting pain comorbidities. ${ }^{43}$ The VZVinfected animals showed less central locomotion in the open-field, which was positively correlated with degree of mechanical hypersensitivity, with no difference in distance traveled. This finding suggests that VZV infection induced an increase in anxiety-like behavior not due to motor impairment, which (unlike the case with peripheral nerve-injured animals) was not reversed by administration of gabapentin. ${ }^{43}$ These findings may help in guiding strategies for the development of novel analgesics for not only sensory but also affective components of VZV-induced persistent pain.

These animal models of VZV-induced persistent pain are models of virus latency, and may not yield information regarding the factors involved in virus reactivation. Reichelt et al. $^{84}$ used human DRG xenografts in the SCID-hu mouse to reveal VZV replication. Viral genomic DNA was present, and viral proteins IE62, IE63, and the early ORF47 kinase were expressed in the majority of neurons and satellite cells in VZV-infected DRG xenograft. ${ }^{84}$ The first event in VZV reactivation from latency is thought to be polykaryon formation between a single neuron and adjacent satellite cells, allowing VZV virions released from satellite cells to infect nearby satellite cells that surround 
other neuronal cell bodies. ${ }^{84}$ Use of autopsy DRG from HZ patients could identify the role of this satellite cell infection in the clinic, perhaps leading to possible avenues of therapeutic intervention.

\section{CLINICAL EVALUATIONS}

Characteristics of the pathophysiological mechanism underlying VZV infection identified in animal models, as described above, demonstrate some parallels with the clinical condition. There are behavioral signs of neuropathic pain and, as in the clinical setting, both sodium channelblocking agents and gabapentin demonstrate some efficacy. Based on results from animal studies, it is hypothesized that distinct pathophysiological mechanisms lead to specific sensory symptoms and signs in patients, which provides a basis for a mechanism-based treatment approach to increasing therapeutic efficacy. ${ }^{85}$ Quantitative sensory testing is an important method for creating a detailed sensory profile of the affected area, one that has advantages over standard nerve conduction studies in investigating the function of small fiber afferents. ${ }^{86}$ Some groups have identified two major subtypes of distinct sensory symptom constellations in PHN, which may be caused by different pathophysiological mechanisms. ${ }^{87}$

\section{CLINICAL TREATMENTS}

Agents generally used for the treatment of neuropathic pain may also show efficacy in PHN because it is a chronic neuropathic pain condition. Currently, selecting appropriate agents in terms of both efficacy and adverse effect profile for any individual is difficult, with treatment often being selected empirically. Improving our understanding of the underlying mechanisms using welldesigned animal models may improve our ability to target treatment effectively.

Postherpetic neuralgia is an area of major therapeutic need; a recent meta-analysis of clinical trial literature revealed that even with the most effective drugs only $30-50 \%$ of patients obtain more than $50 \%$ pain relief, often at the cost of serious adverse effects. ${ }^{79}$ There is also evidence that early treatment may reduce the duration and severity of PHN. ${ }^{88}$ Thus, early diagnosis of both the acute and chronic syndromes may be important in longer-term control. There is evidence that several types of agents may be efficacious in the treatment of PHN. As with all chronic pain syndromes, pharmacological therapy should ideally be part of a multidisciplinary approach to management, but the focus here is on pharmacological strategies.

The use of antiviral therapies in the early stages of the initial HZ episode acts to reduce virus replication and can inhibit the development of prolonged pain. ${ }^{19,89}$ However, antiviral therapy does not prevent pain in all pa- tients, ${ }^{79,89,90}$ as was also identified in an animal model. ${ }^{40-43}$ The supplementation of antiviral therapy with corticosteroids can be beneficial. ${ }^{16,91}$ Combined antiviral therapy with analgesic agents may also be beneficial. ${ }^{15,92}$ The type of analgesic treatment chosen will depend on the pain severity and coexistent morbidity. ${ }^{19}$

\section{Antidepressants}

Tricyclic antidepressants (TCAs) have a number of possible mechanisms of action, including but not limited to inhibition of norepinephrine and serotonin reuptake and sodium channel blockade. ${ }^{93}$ A meta-analysis of TCAs used in the treatment of PHN (amitriptyline, nortriptyline, and desipramine) showed that significant analgesia was obtained ${ }^{79}$ with an earlier analysis also showing TCAs are effective in the treatment of postherpetic pain. ${ }^{81}$ The TCAs, however, including amitriptyline (which is the most widely studied TCA for PHN therapy), have a number of adverse effects, including orthostatic hypertension, sedation, memory loss, urinary retention, constipation and cardiac conduction abnormalities. Adverse effects may be a limiting factor in their prescription, especially in the elderly.

The newer combined serotonin-norepinephrine reuptake inhibitors may also be effective in the treatment of PHN. This includes duloxetine, which is one of the few antidepressants licensed for use in neuropathic pain. $^{94}$

\section{Antiepileptic drugs}

Antiepileptic drugs such as gabapentin or pregabalin have been used for the treatment of neuropathic pain. In a randomized controlled trial (RCT) of patients with PHN, those who received gabapentin had significantly greater improvement in pain scores from 1 week, compared with placebo, ${ }^{95}$ and another study found a significant reduction (i.e., improvement) in average daily pain score with gabapentin, compared with placebo. ${ }^{74}$ The most commonly reported adverse effects are dizziness and somnolence, suggesting that this drug should be titrated slowly in the elderly. The combination of gabapentin and an opioid may result in more effective analgesia at lower doses when compared with either administered alone. $^{96}$

Pregabalin, the successor drug to gabapentin, has been shown in three double-blinded RCTs to provide significant pain relief compared with placebo, as well as improvement for pain-related sleep disturbance. ${ }^{97,98}$ One major advantage of pregabalin over gabapentin is its superior bioavailability which makes it easier to use, without the need of long titration periods. If pregabalin is titrated using a flexible dosage schedule, the adverse effect profile is improved while maintaining analgesia. ${ }^{99,100}$ 


\section{Opioid analgesics}

Although opioid analgesics are an option for the treatment of neuropathic pain, including PHN, concerns over potential adverse effects, as well as misuse and abuse, have led to recommendations (by the International Association for the Study of Pain special interest group and the European and Canadian consensus panels) for this class of drug to be considered as second- or third-line analgesics. ${ }^{101-103}$ A RCT of oxycodone showed that sustained release of the drug resulted in significant pain relief, compared with placebo, ${ }^{104}$ with reduction in both allodynia and spontaneous pain. Double-blind placebocontrolled studies demonstrated that acute infusions of morphine or fentanyl give significant pain relief to PHN patients. ${ }^{105}$ A RCT of tramadol indicated that 6 weeks of sustained release resulted in reduced pain and improved quality of life. ${ }^{106}$ Overall, the evidence indicates that PHN pain may respond to opioid therapy, with titration of the dose required to achieve optimum efficacy and to minimize adverse effects. Constipation, nausea, and sedation are among the common adverse effects associated with opioid therapy; prophylactic treatment of nausea or constipation is often necessary, and can improve patient compliance.

\section{Topical therapies}

Because the patient group most likely to be affected by PHN is often elderly, there are major limitations to using systemic therapies: unacceptable adverse effects can often prevent the dose titration required for efficacy, and may preclude the use of any oral therapies. Topical therapies therefore have clear advantages, in that several established and newer therapies are available, and peripheral mechanisms may be a predominant feature in some PHN patients.

Not all patients fit exactly into one category or the other. Many heterogenous patterns of sensory dysfunction were detected in a large group of PHN patients, ${ }^{39}$ and detailed sensory testing in one PHN patient clearly showed areas of relative preservation in close vicinity to impaired thermal sensation, both within the affected dermatome. ${ }^{107}$ Furthermore, the sensory patterns showed a variation over the time course of PHN. Nonetheless, continuing investigation of mechanism-based treatment approaches seems to be a promising way to establish an optimal therapy with drugs that address the specific mechanisms in each patient.

A topical local anesthetic may provide analgesia. Lidocaine patches (5\%, applied over the area of maximal pain) resulted in significant pain relief in PHN and improved quality of life, ${ }^{108-110}$ and indeed in a RCT there was no significant difference noted between the active (lidocaine) and placebo patch in the incidence of adverse effects. ${ }^{109}$ The use of the lidocaine patch has minimal adverse effects, with the most frequent being mild skin irritation at the site of application. ${ }^{109,111}$ Careful characterization of the type of pain, using quantitative sensory testing, indicated that topical lidocaine was more likely to be effective in those patients with signs of predominant degeneration of nociceptive neurons. The striking finding from this study was that patients with nociceptordeprived skin responded significantly to dermal lidocaine therapy. ${ }^{112}$

Another topical therapy is capsaicin, an agonist of the transient receptor potential vanilloid 1 receptor (TRPV1), which can lead to excitation and the desensitization of nociceptive afferents. Topical capsaicin $(0.075 \%)$ has been found to be effective in relieving pain at 6 weeks, compared with placebo, ${ }^{113}$ and one 60-minute application of a higher concentration of capsaicin (8\%; NGX-4010) resulted in a significantly greater reduction in pain at 2-8 weeks than with a low-concentration $(0.04 \%)$ control patch. ${ }^{114}$ Topical application of capsaicin can often be associated with local irritation and even produces burning pain and hyperalgesia, adverse effects that often lead to discontinuation of its use (even though the reaction typically decreases with repeated applications). The high-dose capsaicin patch is currently in clinical development (e.g., for use with topical anesthetics: NCT00916942, ClinicalTrials.gov). Despite the high concentration, the patch seems to be well tolerated, with minimal adverse effects. ${ }^{14,115}$

\section{Interventional therapies}

There is limited evidence of good quality for the benefit of any interventional therapies, and further studies are required. Interventional options include sympathetic or other nerve blocks, intrathecal injection, or spinal cord stimulation. Sympathetic nerve blocks have been used for PHN, although these may be more effective in the acute phase. ${ }^{116}$ Peripheral nerve blocks have also been used; for example, intercostal nerve blocks were reported to result in long-lasting pain relief for PHN. ${ }^{117}$ Pulsed radio-frequency lesioning of the DRG has been assessed in an open case series, and did show some benefit; however, as with most interventions, a study designed to account for the placebo effect is required. ${ }^{118}$

Use of lidocaine and methylprednisolone combined (via intrathecal administration) appears to be associated with pain relief in PHN patients, ${ }^{119}$ although this has potentially dangerous short-term and long-term adverse effects and the trial has not yet been replicated. ${ }^{79}$ Spinal cord stimulation has been used for the treatment of neuropathic pain, and some PHN patients have obtained relief with temporary percutaneous spinal cord stimulation. ${ }^{120}$ Given the limited evidence available specifically for interventional therapies in PHN, it is difficult to recommend any particular strategy.

Recent guidelines on evidence-based treatment for neuropathic pain, including PHN, have recommended 
TCAs, antiepileptics, and topical lidocaine as first-line analgesics, with opioids and tramadol as second-line treatments and topical capsaicin as third-line therapies. ${ }^{101-103}$ Combination therapy may provide additive or synergistic analgesia, although there is little evidence for the benefit or harm provided by such combinations in treatment of PHN.

\section{FUTURE DIRECTIONS}

With the introduction of widespread childhood vaccination and also an aging population, the incidence of $\mathrm{HZ}$ and thereby PHN is initially expected to increase in the future. The epidemiological impact of varicella and $\mathrm{HZ}$ vaccination on $\mathrm{HZ}$ and $\mathrm{PHN}$ incidence needs to be monitored to allow for more accurate mathematical modeling. One crucial aspect of the ongoing efforts to alleviate PHN is the need for an accepted definition of acute HZ and PHN, to allow for epidemiological surveillance and consistent inclusion criteria for RCTs in PHN patients. Assessment of the effect of PHN and its treatment on quality of life, physical and mental activities, and social relationships of PHN patients is an important factor for future evaluation therapeutic strategies in PHN.

Methods for earlier detection of HZ by patients or clinicians need to be developed, so that adequate preventive treatment can be given before complications such as PHN occur. An important topic for future study is the determination of a biological marker for recovery from PHN. Given that the majority of HZ patients recover from their pain, pruritus, and other symptoms, evaluation of how symptom resolution is brought about could point the way to the development of treatments to hasten or facilitate this process.

\section{REFERENCES}

1. Cohrs RJ, Gilden DH, Mahalingam R. Varicella zoster virus latency, neurological disease and experimental models: an update. Front Biosci 2004;9:751-762.

2. Wu CL, Raja SN. An update on the treatment of postherpetic neuralgia. J Pain 2008;9(1 Suppl 1):S19-S30.

3. Seward J, Galil K, Wharton M. Epidemiology of varicella. In: Arvin AM, Gershon AA, editors. Varicella-zoster virus: virology and clinical management. Cambridge: Cambridge University Press, 2000:187-205.

4. Oxman MN. Clinical manifestations of herpes zoster. In: Arvin AM, Gershon AA. Varicella-zoster virus: Virology and clinical management. Cambridge: Cambridge University Press, 2000: 246-275.

5. Sampathkumar P, Drage LA, Martin DP. Herpes zoster (shingles) and postherpetic neuralgia. Mayo Clin Proc 2009;84:274-280.

6. Dworkin RH, Nagasako EM, Johnson RW, Griffin DR. Acute pain in herpes zoster: the famciclovir database project. Pain 2001; 94:113-119.

7. Haanpää M, Laippala $\mathrm{P}$, Nurmikko T. Pain and somatosensory dysfunction in acute herpes zoster. Clin J Pain 1999;15:78-84.

8. Haanpää M, Laippala $\mathrm{P}$, Nurmikko T. Allodynia and pinprick hypesthesia in acute herpes zoster, and the development of postherpetic neuralgia. J Pain Symptom Manage 2000;20:50-58.

9. Hope-Simpson RE. Postherpetic neuralgia. J R Coll Gen Pract 1975;25:571-575
10. Meister W, Neiss A, Gross G, et al. A prognostic score for postherpetic neuralgia in ambulatory patients. Infection 1998;26: 359-363.

11. Ragozzino MW, Melton LJ 3rd, Kurland LT, Chu CP, Perry HO. Population-based study of herpes zoster and its sequelae. Medicine (Baltimore) 1982;61:310-316.

12. Hall GC, Carroll D, Parry D, McQuay HJ. Epidemiology and treatment of neuropathic pain: the UK primary care perspective. Pain 2006; 122:156-162.

13. Gauthier A, Breuer J, Carrington D, Martin M, Rémy V. Epidemiology and cost of herpes zoster and post-herpetic neuralgia in the United Kingdom. Epidemiol Infect 2009;137:38-47.

14. Schmader K, Gnann JW Jr, Watson CP. The epidemiological, clinical, and pathological rationale for the herpes zoster vaccine. J Infect Dis 2008;197 Suppl 2:S207-S215.

15. Dworkin RH, Schmader KE. Treatment and prevention of postherpetic neuralgia. Clin Infect Dis 2003;36:877-882.

16. Wood MJ, Johnson RW, McKendrick MW, Taylor J, Mandal BK, Crooks J. A randomized trial of acyclovir for 7 days or 21 days with and without prednisolone for treatment of acute herpes zoster. N Engl J Med 1994;330:896-900.

17. Nagasako EM, Johnson RW, Griffin DR, Dworkin RH. Rash severity in herpes zoster: correlates and relationship to postherpetic neuralgia. J Am Acad Dermatol 2002;46:834-839.

18. Volpi A, Gatti A, Pica F, Bellino S, Marsella LT, Sabato AF. Clinical and psychosocial correlates of post-herpetic neuralgia. J Med Virol 2008;80:1646-1652.

19. Dworkin RH, Johnson RW, Breuer J, et al. Recommendations for the management of herpes zoster. Clin Infect Dis 2007;44 Suppl 1:S1-26.

20. Thyregod HG, Rowbotham MC, Peters M, Possehn J, Berro M, Petersen KL. Natural history of pain following herpes zoster. Pain 2007;128:148-156.

21. Dworkin RH, Gnann JW Jr, Oaklander AL, Raja SN, Schmader KE, Whitley RJ. Diagnosis and assessment of pain associated with herpes zoster and postherpetic neuralgia. J Pain 2008;9(1 Suppl 1):S37-S44.

22. Schmader K. Postherpetic neuralgia in immunocompetent elderly people. Vaccine 1998;16:1768-1770.

23. Fields HL, Rowbotham M, Baron R. Postherpetic neuralgia: irritable nociceptors and deafferentation. Neurobiol Dis 1998;5: 209-227.

24. Oxman MN, Levin MJ, Johnson GR, et al.; Shingles Prevention Study Group. A vaccine to prevent herpes zoster and postherpetic neuralgia in older adults. N Engl J Med 2005;352:2271-2284.

25. Arani RB, Soong SJ, Weiss HL, et al. Phase specific analysis of herpes zoster associated pain data: a new statistical approach. Stat Med 2001;20:2429-2439.

26. Desmond RA, Weiss HL, Arani RB, et al. Clinical applications for change-point analysis of herpes zoster pain. J Pain Symptom Manage 2002;23:510-516.

27. Jung BF, Johnson RW, Griffin DR, Dworkin RH. Risk factors for postherpetic neuralgia in patients with herpes zoster. Neurology 2004;62:1545-1551.

28. Dworkin RH, Portenoy RK. Pain and its persistence in herpes zoster. Pain 1996;67:241-251.

29. Oaklander AL. The density of remaining nerve endings in human skin with and without postherpetic neuralgia after shingles [Erratum in: Pain 2001;94:325]. Pain 2001;92:139-145.

30. Rowbotham MC, Yosipovitch G, Connolly MK, Finlay D, Forde G, Fields HL. Cutaneous innervation density in the allodynic form of postherpetic neuralgia. Neurobiol Dis 1996;3:205-214.

31. Baron R, Saguer M. Postherpetic neuralgia. Are C-nociceptors involved in signalling and maintenance of tactile allodynia? Brain 1993;116:1477-1496.

32. Baron R, Saguer M. Mechanical allodynia in postherpetic neuralgia: evidence for central mechanisms depending on nociceptive C-fiber degeneration. Neurology 1995;45(12 Suppl 8):S63-S65.

33. Truini A, Galeotti F, Haanpaa M, et al. Pathophysiology of pain in postherpetic neuralgia: a clinical and neurophysiological study. Pain 2008;140:405-410.

34. Nurmikko T, Bowsher D. Somatosensory findings in postherpetic neuralgia. J Neurol Neurosurg Psychiatry 1990;53:135-141. 
35. Geha PY, Baliki MN, Wang X, Harden RN, Paice JA, Apkarian AV. Brain dynamics for perception of tactile allodynia (touchinduced pain) in postherpetic neuralgia. Pain 2008;138:641-656.

36. Scholz J, Broom DC, Youn DH, et al. Blocking caspase activity prevents transsynaptic neuronal apoptosis and the loss of inhibition in lamina II of the dorsal horn after peripheral nerve injury. J Neurosci 2005;25:7317-7323.

37. Ji RR, Woolf CJ. Neuronal plasticity and signal transduction in nociceptive neurons: implications for the initiation and maintenance of pathological pain. Neurobiol Dis 2001;8:1-10.

38. Tal M, Bennett GJ. Extra-territorial pain in rats with a peripheral mononeuropathy: mechano-hyperalgesia and mechano-allodynia in the territory of an uninjured nerve. Pain 1994;57:375-382.

39. Pappagallo M, Oaklander AL, Quatrano-Piacentini AL, Clark MR, Raja SN. Heterogenous patterns of sensory dysfunction in postherpetic neuralgia suggest multiple pathophysiologic mechanisms. Anesthesiology 2000;92:691-698.

40. Sadzot-Delvaux C, Merville-Louis MP, Delrée P, et al. An in vivo model of varicella-zoster virus latent infection of dorsal root ganglia. J Neurosci Res 1990;26:83-89.

41. Garry EM, Delaney A, Anderson HA, et al. Varicella zoster virus induces neuropathic changes in rat dorsal root ganglia and behavioral reflex sensitisation that is attenuated by gabapentin or sodium channel blocking drugs. Pain 2005;118:97-111.

42. Dalziel RG, Bingham S, Sutton D, et al. Allodynia in rats infected with varicella zoster virus: a small animal model for post-herpetic neuralgia. Brain Res Brain Res Rev 2004;46:234-242.

43. Hasnie FS, Breuer J, Parker S, et al. Further characterization of a rat model of varicella zoster virus-associated pain: relationship between mechanical hypersensitivity and anxiety-related behavior, and the influence of analgesic drugs. Neuroscience 2007;144: 1495-1508.

44. Oliver SL, Zerboni L, Sommer M, Rajamani J, Arvin AM. Development of recombinant varicella-zoster viruses expressing luciferase fusion proteins for live in vivo imaging in human skin and dorsal root ganglia xenografts. J Virol Methods 2008;154: 182-193.

45. Kinchington PR, Hougland JK, Arvin AM, Ruyechan WT, Hay J. The varicella-zoster virus immediate-early protein IE62 is a major component of virus particles. J Virol 1992;66:359-366.

46. Sato B, Ito H, Hinchliffe S, Sommer MH, Zerboni L, Arvin AM. Mutational analysis of open reading frames 62 and 71, encoding the varicella-zoster virus immediate-early transactivating protein, IE62, and effects on replication in vitro and in skin xenografts in the SCID-hu mouse in vivo. J Virol 2003;77:5607-5620.

47. Kress M, Fickenscher H. Infection by human varicella-zoster virus confers norepinephrine sensitivity to sensory neurons from rat dorsal root ganglia. FASEB J 2001;15:1037-1043.

48. Cummins TR, Dib-Hajj SD, Black JA, Waxman SG. Sodium channels and the molecular pathophysiology of pain. Prog Brain Res 2000;129:3-19.

49. Hökfelt T, Zhang X, Wiesenfeld-Hallin Z. Messenger plasticity in primary sensory neurons following axotomy and its functional implications. Trends Neurosci 1994;17:22-30.

50. Woolf CJ, Salter MW. Neuronal plasticity: increasing the gain in pain. Science 2000;288:1765-1769.

51. Xiao HS, Huang QH, Zhang FX, et al. Identification of gene expression profile of dorsal root ganglion in the rat peripheral axotomy model of neuropathic pain. Proc Natl Acad Sci U S A 2002;99:8360-8365.

52. Villar MJ, Wiesenfeld-Hallin Z, Xu XJ, Theodorsson E, Emson PC, Hökfelt T. Further studies on galanin-, substance P-, and CGRP-like immunoreactivities in primary sensory neurons and spinal cord: effects of dorsal rhizotomies and sciatic nerve lesions. Exp Neurol 1991;112:29-39.

53. Tsujino H, Kondo E, Fukuoka T, et al. Activating transcription factor 3 (ATF3) induction by axotomy in sensory and motoneurons: a novel neuronal marker of nerve injury. Mol Cell Neurosci 2000;15:170-182.

54. Woolf CJ, Mannion RJ. Neuropathic pain: aetiology, symptoms, mechanisms, and management. Lancet 1999;353:1959-1964.
55. Woolf CJ, Costigan M. Transcriptional and posttranslational plasticity and the generation of inflammatory pain. Proc Natl Acad Sci U S A 1999;96:7723-7730.

56. Waxman SG. The molecular pathophysiology of pain: abnormal expression of sodium channel genes and its contributions to hyperexcitability of primary sensory neurons. Pain 1999;82 Suppl 1:S133-S140.

57. Black JA, Waxman SG. Sodium channel expression: a dynamic process in neurons and non-neuronal cells. Dev Neurosci 1996; 18:139-152.

58. Kim CH, Oh Y, Chung JM, Chung K. The changes in expression of three subtypes of TTX sensitive sodium channels in sensory neurons after spinal nerve ligation. Brain Res Mol Brain Res 2001;95:153-161.

59. Porreca F, Lai J, Bian D, et al. A comparison of the potential role of the tetrodotoxin-insensitive sodium channels, PN3/SNS and NaN/SNS2, in rat models of chronic pain [Erratum in: Proc Natl Acad Sci U S A 1999;96:10548]. Proc Natl Acad Sci U S A 1999;96:7640-7644.

60. Erichsen HK, Blackburn-Munro G. Pharmacological characterisation of the spared nerve injury model of neuropathic pain. Pain 2002;98:151-161.

61. Erichsen HK, Hao JX, Xu XJ, Blackburn-Munro G. A comparison of the antinociceptive effects of voltage-activated $\mathrm{Na}^{+}$channel blockers in two rat models of neuropathic pain. Eur J Pharmacol 2003;458:275-282.

62. Laughlin TM, Tram KV, Wilcox GL, Birnbaum AK. Comparison of antiepileptic drugs tiagabine, lamotrigine, and gabapentin in mouse models of acute, prolonged, and chronic nociception. J Pharmacol Exp Ther 2002;302:1168-1175.

63. Chabal C, Jacobson L, Mariano A, Chaney E, Britell CW. The use of oral mexiletine for the treatment of pain after peripheral nerve injury. Anesthesiology 1992;76:513-517.

64. Bayer K, Ahmadi S, Zeilhofer HU. Gabapentin may inhibit synaptic transmission in the mouse spinal cord dorsal horn through a preferential block of P/Q-type $\mathrm{Ca}^{2+}$ channels. Neuropharmacology 2004;46:743-749.

65. Luo ZD, Calcutt NA, Higuera ES, et al. Injury type-specific calcium channel $\alpha_{2} \delta-1$ subunit up-regulation in rat neuropathic pain models correlates with antiallodynic effects of gabapentin. J Pharmacol Exp Ther 2002;303:1199-1205.

66. Newton RA, Bingham S, Case PC, Sanger GJ, Lawson SN. Dorsal root ganglion neurons show increased expression of the calcium channel $\alpha_{2} \delta-1$ subunit following partial sciatic nerve injury. Brain Res Mol Brain Res 2001;95:1-8.

67. Rogawski MA, Löscher W. The neurobiology of antiepileptic drugs for the treatment of nonepileptic conditions. Nat Med 2004; 10:685-692.

68. Kanai A, Sarantopoulos C, McCallum JB, Hogan Q. Painful neuropathy alters the effect of gabapentin on sensory neuron excitability in rats. Acta Anaesthesiol Scand 2004;48:507-512.

69. Pan HL, Eisenach JC, Chen SR. Gabapentin suppresses ectopic nerve discharges and reverses allodynia in neuropathic rats. J Pharmacol Exp Ther 1999;288:1026-1030.

70. Hunter JC, Gogas KR, Hedley LR, et al. The effect of novel anti-epileptic drugs in rat experimental models of acute and chronic pain. Eur J Pharmacol 1997;324:153-160.

71. Abdi S, Lee DH, Chung JM. The anti-allodynic effects of amitriptyline, gabapentin, and lidocaine in a rat model of neuropathic pain. Anesth Analg 1998;87:1360-1366.

72. Mao J, Chen LL. Gabapentin in pain management. Anesth Analg 2000;91:680-687.

73. Beydoun A. Postherpetic neuralgia: role of gabapentin and other treatment modalities. Epilepsia 1999;40 Suppl 6:S51-S56.

74. Rowbotham M, Harden N, Stacey B, Bernstein P, Magnus-Miller L. Gabapentin for the treatment of postherpetic neuralgia: a randomized controlled trial. JAMA 1998;280:1837-1842.

75. Chaplan SR, Malmberg AB, Yaksh TL. Efficacy of spinal NMDA receptor antagonism in formalin hyperalgesia and nerve injury evoked allodynia in the rat. J Pharmacol Exp Ther 1997;280: $829-838$

76. Dickenson AH, Sullivan AF. Evidence for a role of the NMDA receptor in the frequency dependent potentiation of deep rat dor- 
sal horn nociceptive neurones following $\mathrm{C}$ fibre stimulation. Neuropharmacology 1987;26:1235-1238.

77. Hocking G, Cousins MJ. Ketamine in chronic pain management: an evidence-based review. Anesth Analg 2003;97:1730-1739.

78. Sang CN, Booher S, Gilron I, Parada S, Max MB. Dextromethorphan and memantine in painful diabetic neuropathy and postherpetic neuralgia: efficacy and dose-response trials. Anesthesiology 2002;96:1053-1061.

79. Hempenstall K, Nurmikko TJ, Johnson RW, A'Hern RP, Rice AS. Analgesic therapy in postherpetic neuralgia: a quantitative systematic review. PLoS Med 2005;2:e164.

80. Rog DJ, Nurmikko TJ, Friede T, Young CA. Randomized, controlled trial of cannabis-based medicine in central pain in multiple sclerosis. Neurology 2005;65:812-819.

81. Sindrup SH, Otto M, Finnerup NB, Jensen TS. Antidepressants in the treatment of neuropathic pain. Basic Clin Pharmacol Toxicol 2005;96:399-409.

82. Meyer-Rosberg K, Kvarnström A, Kinnman E, Gordh T, Nordfors LO, Kristofferson A. Peripheral neuropathic pain: a multidimensional burden for patients. Eur J Pain 2001;5:379-389.

83. Nicholson B, Verma S. Comorbidities in chronic neuropathic pain. Pain Med 2004;5 Suppl 1:S9-S27.

84. Reichelt M, Zerboni L, Arvin AM. Mechanisms of varicellazoster virus neuropathogenesis in human dorsal root ganglia. J Virol 2008;82:3971-3983.

85. Jensen TS, Baron R. Translation of symptoms and signs into mechanisms in neuropathic pain. Pain 2003;102:1-8.

86. Cruccu G, Anand P, Attal N, et al. EFNS guidelines on neuropathic pain assessment. Eur J Neurol 2004;11:153-162.

87. Rowbotham MC, Fields HL. The relationship of pain, allodynia and thermal sensation in post-herpetic neuralgia. Brain 1996;119: 347-354.

88. Bowsher D. The effects of pre-emptive treatment of post-herpetic neuralgia with amitriptyline: a randomized, double-blind, placebocontrolled trial. J Pain Symptom Manage 1997;13:327-331.

89. Schmader KE, Dworkin RH. Natural history and treatment of herpes zoster. J Pain 2008;9(1 Suppl 1):S3-S9.

90. Surman OS, Flynn T, Schooley RT, et al. A double-blind, placebocontrolled study of oral acyclovir in postherpetic neuralgia. Psychosomatics 1990;31:287-292.

91. Whitley RJ, Weiss H, Gnann JW Jr, et al.; The National Institute of Allergy and Infectious Diseases Collaborative Antiviral Study Group. Acyclovir with and without prednisone for the treatment of herpes zoster: a randomized, placebo-controlled trial. Ann Intern Med 1996;125:376-383.

92. Dworkin RH, Perkins FM, Nagasako EM. Prospects for the prevention of postherpetic neuralgia in herpes zoster patients. Clin J Pain 2000;16(2 Suppl):S90-S100.

93. Dick IE, Brochu RM, Purohit Y, Kaczorowski GJ, Martin WJ, Priest BT. Sodium channel blockade may contribute to the analgesic efficacy of antidepressants. J Pain 2007;8:315-324.

94. Zin CS, Nissen LM, Smith MT, O'Callaghan JP, Moore BJ. An update on the pharmacological management of post-herpetic neuralgia and painful diabetic neuropathy. CNS Drugs 2008;22:417442.

95. Rice AS, Maton S. Gabapentin in postherpetic neuralgia: a randomised, double blind, placebo controlled study. Pain 2001;94: 215-224.

96. Gilron I, Biederman J, Jhamandas K, Hong M. Gabapentin blocks and reverses antinociceptive morphine tolerance in the rat pawpressure and tail-flick tests. Anesthesiology 2003;98:1288-1292.

97. Frampton JE, Foster RH. Pregabalin: in the treatment of postherpetic neuralgia. Drugs 2005;65:111-118.

98. Sabatowski R, Gálvez R, Cherry DA, et al. Pregabalin reduces pain and improves sleep and mood disturbances in patients with post-herpetic neuralgia: results of a randomised, placebo-controlled clinical trial. Pain 2004;109:26-35.

99. Stacey BR, Barrett JA, Whalen E, Phillips KF, Rowbotham MC. Pregabalin for postherpetic neuralgia: placebo-controlled trial of fixed and flexible dosing regimens on allodynia and time to onset of pain relief. J Pain 2008;9:1006-1017.
100. Baron R, Brunnmüller U, Brasser M, May M, Binder A. Efficacy and safety of pregabalin in patients with diabetic peripheral neuropathy or postherpetic neuralgia: open-label, non-comparative, flexible-dose study. Eur J Pain 2008;12:850-858.

101. Attal N, Cruccu G, Haanpää M, et al. EFNS guidelines on pharmacological treatment of neuropathic pain. Eur J Neurol 2006; 13:1153-1169.

102. Dworkin RH, O'Connor AB, Backonja M, et al. Pharmacologic management of neuropathic pain: evidence-based recommendations. Pain 2007;132:237-251.

103. Moulin DE, Clark AJ, Gilron I, et al. Pharmacological management of chronic neuropathic pain: consensus statement and guidelines from the Canadian Pain Society. Pain Res Manag 2007;12: $13-21$.

104. Watson CP, Babul N. Efficacy of oxycodone in neuropathic pain: a randomized trial in postherpetic neuralgia. Neurology 1998;50: $1837-1841$.

105. Rowbotham MC, Reisner-Keller LA, Fields HL. Both intravenous lidocaine and morphine reduce the pain of postherpetic neuralgia. Neurology 1991;41:1024-1028.

106. Boureau F, Legallicier P, Kabir-Ahmadi M. Tramadol in postherpetic neuralgia: a randomized, double-blind, placebo-controlled trial. Pain 2003;104:323-331.

107. Petersen KL, Fields HL, Brennum J, Sandroni P, Rowbotham MC. Capsaicin evoked pain and allodynia in post-herpetic neuralgia. Pain 2000;88:125-133.

108. Davies PS, Galer BS. Review of lidocaine patch $5 \%$ studies in the treatment of postherpetic neuralgia. Drugs 2004;64:937-947.

109. Galer BS, Rowbotham MC, Perander J, Friedman E. Topical lidocaine patch relieves postherpetic neuralgia more effectively than a vehicle topical patch: results of an enriched enrollment study. Pain 1999;80:533-538.

110. Meier T, Wasner G, Faust M, et al. Efficacy of lidocaine patch $5 \%$ in the treatment of focal peripheral neuropathic pain syndromes: a randomized, double-blind, placebo-controlled study. Pain 2003; 106:151-158.

111. Galer BS, Jensen MP, Ma T, Davies PS, Rowbotham MC. The lidocaine patch $5 \%$ effectively treats all neuropathic pain qualities: results of a randomized, double-blind, vehicle-controlled, 3 -week efficacy study with use of the neuropathic pain scale. Clin J Pain 2002;18:297-301.

112. Wasner G, Kleinert A, Binder A, Schattschneider J, Baron R. Postherpetic neuralgia: topical lidocaine is effective in nociceptor-deprived skin. J Neurol 2005;252:677-686.

113. Watson CP, Tyler KL, Bickers DR, Millikan LE, Smith S, Coleman E. A randomized vehicle-controlled trial of topical capsaicin in the treatment of postherpetic neuralgia. Clin Ther 1993; 15:510-526.

114. Backonja M, Wallace MS, Blonsky ER, et al.; NGX-4010 C116 Study Group. NGX-4010, a high-concentration capsaicin patch, for the treatment of postherpetic neuralgia: a randomised, doubleblind study [Erratum in: Lancet Neurol 2009;8:31]. Lancet Neurol 2008;7:1106-1112.

115. Binder A, Baron R. Postherpetic neuralgia: fighting pain with fire. Lancet Neurology 2008;7:1077-1078.

116. Wu CL, Marsh A, Dworkin RH. The role of sympathetic nerve blocks in herpes zoster and postherpetic neuralgia. Pain 2000;87: 121-129.

117. Doi K, Nikai T, Sakura S, Saito Y. Intercostal nerve block with 5\% tetracaine for chronic pain syndromes. J Clin Anesth 2002; 14:39-41.

118. Kim YH, Lee CJ, Lee SC, et al. Effect of pulsed radiofrequency for postherpetic neuralgia. Acta Anaesthesiol Scand 2008;52: $1140-1143$.

119. Kotani N, Kushikata T, Hashimoto H, et al. Intrathecal methylprednisolone for intractable postherpetic neuralgia. N Engl J Med 2000;343:1514-1519.

120. Harke H, Gretenkort P, Ladleif HU, Koester P, Rahman S. Spinal cord stimulation in postherpetic neuralgia and in acute herpes zoster pain. Anesth Analg 2002;94:694-700. 